\title{
Evaluation of Biochemical, Hematological and Antioxidant Properties in Mice Exposed to a Triherbal (Nigella sativa, Carica papaya and Boswellia sacra) Formular
}

\author{
Kehinde Sowunmi ${ }^{1, ~ *}$, Adebayo Sofiyyah Modupeola ${ }^{1}$, Adesiyan Ayobami Lawal ${ }^{2}$, \\ Kade Emmanuel Ayomikun ${ }^{2}$, Gurpreet Kaur ${ }^{3}$ \\ ${ }^{1}$ Department of Cell Biology and Genetics, University of Lagos (UNILAG), Akoka, Lagos, Nigeria \\ ${ }^{2}$ Department of Microbiology, University of Lagos (UNILAG), Akoka, Lagos, Nigeria \\ ${ }^{3}$ Department of Health and Health Care Administration, Swami Rama Himalayan University (SRHU), Dehradun, India
}

Email address:

sowunmikehinde111@gmail.com (K. Sowunmi)

${ }^{*}$ Corresponding author

\section{To cite this article:}

Kehinde Sowunmi, Adebayo Sofiyyah Modupeola, Adesiyan Ayobami Lawal, Kade Emmanuel Ayomikun, Gurpreet Kaur. Evaluation of Biochemical, Hematological and Antioxidant Properties in Mice Exposed to a Triherbal (Nigella sativa, Carica papaya and Boswellia sacra) Formular. Cell Biology. Vol. 9, No. 1, 2021, pp. 7-15. doi: 10.11648/j.cb.20210901.12

Received: January 26, 2021; Accepted: February 6, 2021; Published: April 29, 2021

\begin{abstract}
Nigella sativa, Carica papaya and Boswellia sacra are medicinal plants in the commonly used in folkloric medicine due to the presence of its immense therapeutic properties. Fifty (50) female albino mice weighing between $15-22 \mathrm{~g}$ were divided into five groups of 10 mice each. Animal in group 1 served as control group and were administered distilled water while animal in group 2 were given $2 \mathrm{ml}$ of cisplatin (orally). Animal in group 3-5 were given orally; $100 \mathrm{mg} / \mathrm{kg}$ (low dose), $200 \mathrm{mg} / \mathrm{kg}$ (medium dose) and $400 \mathrm{mg} / \mathrm{kg}$ (high dose) of triherbal preparation. The feeding regimens lasted for 28 days. After 28 days, mammary gland and blood samples were collected for haematological and antioxidant analysis. The triherbal formula decreased the GSH and MDA levels of mice treated with $100 \mathrm{mg} / \mathrm{kg}$ and $400 \mathrm{mg} / \mathrm{kg}$ doses compare to control. The measurement of total protein content, SOD and CAT increased in treated animals compared to control. However, RBC (Red Blood Cell) counts significantly decreased in the low, medium and high dose groups $(0.95 \pm 0.08,6.57 \pm 0.08$ and $3.55 \pm 0.55 \mathrm{x}$ $10^{6}$ cells $/ \mathrm{mm}^{3}$ respectively) compared to control $(7.34 \pm 0.40)$ at $\mathrm{P}<0.05$. Also, significant decreases $(\mathrm{P}<0.05)$ in the level of the total WBC (White Blood Cell) count, platelet count, PCV (Packed Cell Volume) and Hb (haemoglobin) concentration were observed. The decreases were dose dependent. The MCH (Mean Corpuscular Haemoglobin) and MCHC (Mean Corpuscular Haemoglobin Concentration) except MCV (Mean Corpuscular Volume) significantly decreased in treated group only. The triherbal formulation exhibited significant antioxidant activities showing increased levels of SOD, CAT and Protein content due to activation of the enzyme involve in detoxification of free radicals and decreased in the level of GSH and MDA due to accumulation of peroxides and $\mathrm{H}_{2} \mathrm{O}_{2}$. Also, decreased in haematological parameters due to the presence of phytochemicals such as phenol, resins, saponins, sterols, tannis and terpenes in the triherbal formula. Therefore, it has potential to induce haematotoxicity hence consumption of high concentrations should be discouraged.
\end{abstract}

Keywords: Nigella Sativa, Carica Papaya, Boswellia Sacra, Antioxidant and Haematology

\section{Introduction}

Over the years, plants have been used by humans as medicine to treat a vast number of diseases. The use of medicinal plants cuts across cultural lines as various traditional systems of medicine [15]. In Africa, the use of
Egyptian traditional medicine dates from about 2900 B.C. In most African traditional societies, herbal remedies were often prepared as crude extract of medicinal plant organs such as leaves, roots, flowers and barks [16, 34].

Today, the popularity of traditional medicine has greatly increased across the world in both developed and developing nations. The World Health Organization estimates that about 
$80 \%$ of the populations in developing nations use traditional medicines, most of which are plant based remedies as complementary or alternative medicine [37].

Various factors can be attributed to the increase in the use of plant based remedies. They may include: economic considerations such as high cost of conventional medicines, perceived lower toxicity and fewer side effects of plant based medicines as these plants have been used before. To add on to the upsurge is the existence of diseases like cancer, to which no cure exists and the emergence of new diseases. The increased cases of drug resistance which are being encountered with the use of conventional medicines have favorably contributed to the use of plant based remedies [1, 9, 28].

Plants have played an important role in drug discovery. For example vincristine and vinblastine which are used for the treatment of cancer are obtained from Catharanthus roseus. Quinine an antimalarial is obtained from Cinchona ledgeriana while digoxin is obtained from Digitalis lanata and is used as a cardiotonic [15].

There are various ways through which plants can be used as sources of drugs. They include: using the whole plant or part of it as an herbal remedy, isolating bioactive compounds for direct use as therapeutic agents such as morphine. Plants can also provide raw materials for partial synthesis of drugs with higher activity or lower toxicity or they can be used as molecular models to produce new drugs [15].

Despite the immense health benefits realized from use of plants as medicines, several challenges still exist such as insufficient scientific data to support use of some herbal remedies, lack of standardized formulation of herbal remedies and adulteration of herbal materials. According to the WHO, the assessment of the safety and efficacy of herbal remedies still remains a challenge [14, 36].

The use of medicinal plants is a practice among humans that has been passed down from one generation to another and plays a role in the development of human cultures and various traditional systems of medicine worldwide. According to the WHO, traditional medicine (TM) is defined as, "the sum total of knowledge, skills and practices based on the theories, beliefs and experiences indigenous to different cultures that are used to maintain health, as well as to prevent, diagnose, improve or treat physical and mental illnesses" [36]. Based on fossil records, the use of medicinal plants dates back to the middle Paleolithic age 60000 years ago. These plants had a variety of uses such as food seasoning, weapons and medicines [19].

Medicinal plants can be described as "any plant which, in one or more of its organs, contains substances that can be used for therapeutic purposes or as precursors for the synthesis of useful drugs". The therapeutically useful phytochemicals obtained from plants include the alkaloids, flavonoids, tannins and phenolic compounds [11, 33]. In most plants, the quantity and the composition of bioactive compounds present are influenced by genotype, extraction procedure and environmental conditions [30, 35].

Plants are major part of most traditional medicine systems and a variety of conventional drugs have been obtained from plants following ethnobotanical leads from traditional remedies. Natural products and their derivatives represent over $50 \%$ of all drugs in clinical use worldwide according to Maridass and Britto [25].

In spite of these challenges, medicinal plants have a promising future to act as preventive medicine against various diseases and also as complementary medicine alongside conventional treatments so as to increase efficacy or reduce side effects of conventional therapies [19]. This study focused on establishing some medicinal plants used in treatment of cancer and also screen for their antioxidant activity and haematological parameters.

\section{Materials and Methods}

\subsection{Plant Materials and Sample Preparations}

Leaves of Carica papaya were sourced from Baale farmland, Asese, Obafemi Owode Government in Ogun State. The leaves were washed, air dried, and crushed to a powder with an electric micronizer. The black seeds and Frankincense were collected from the local markets. After that the seeds were grinded into fine powder form to prepare the crude alcoholic extracts. Two hundred gram of each of powdered plant material was kept in $1000 \mathrm{ml}$ of alcohol in conical flask. The mouth of the conical flasks were covered with aluminum foil and kept in a room temperature for 48 hours for complete elucidation of active materials to dissolve in ethanol. Then, the extracts were filtered by using muslin cloth followed by filter paper. The solvent form the extracts were removed with water bath at temperature of $40^{\circ} \mathrm{C}$. Finally, the residues were collected and used for the experiment.

\subsection{Animal Procurement and Conditioning}

Fifty adult female mice were sourced from a local breeder at Otta in Ogun-State. The mice weighed between $14 \mathrm{~g}-25 \mathrm{~g}$. They were kept in well ventilated cages cushioned with saw dust in the animal house of the Department Cell biology and Genetics, Faculty of science, University of Lagos. They were acclimatized for one week before actual experiment and kept under standard conditions of room temperature and 12:12 hours of light and dark cycle respectively. The mice were fed with standardized pellet and tap water ad libitum. The mice cages were regularly cleaned and saw dust changed every day.

\subsection{Acute Toxicity $\left(L_{50}\right)$ Study}

A separate experiment was carried out to study the acute toxicity of the extracts on mice. Normal healthy female mice were randomly divided into 5 groups which fed with the vehicle-treated "control" groups (distill water) and three concentration of extract-treated "experimental" groups, totally making up to 5 groups of 10 animals per each group. Extract (50, 100, 200, 400 and $1000 \mathrm{mg} / \mathrm{kg}$ body weight) were orally administered to different test groups and control 
groups were separated. All the mice were allowed access to food and water. Behaviour changes and mortality were observed and recorded over a period of 72 hours. The LD50 was estimated from the graph of percentage (\%) mortality (converted to probit) against log-dose of the extract, probit 5 being $50 \%$ [2].

\subsection{Experimental Design and Grouping}

The animals were divided in five groups of ten mice each. All mice were fed by normal diet and water ad-libitum. Mice in group A served as positive control, group B served as negative control, groups $\mathrm{C}, \mathrm{D}$, and $\mathrm{E}$ were administered by the alcoholic extracts once daily for a period of 28 days, with single dose of Cisplatin, 100, 200 and $400 \mathrm{mg} / \mathrm{kg}$ Body weight, respectively. All the mice were weighed three times a week and kept under normal temperature during the period of study.

Table 1. Shows treatment and duration of groups.

\begin{tabular}{lll}
\hline Group & Route of Administration & Duration \\
\hline A & Normal control+ distill water orally & 28 days \\
B & Cisplatin $(2 \mathrm{ml} \mathrm{p.u)} \mathrm{orally}$ & 28 days \\
C & $100 \mathrm{mg} / \mathrm{kg}+$ cisplatin $(2 \mathrm{ml} \mathrm{p.u})$ orally & 28 days \\
D & $200 \mathrm{mg} / \mathrm{kg}+$ cisplatin $(2 \mathrm{ml} \mathrm{p.u})$ orally & 28 days \\
E & $400 \mathrm{mg} / \mathrm{kg}+$ cisplatin $(2 \mathrm{ml} \mathrm{p.u})$ orally & 28 days \\
\hline
\end{tabular}

Animals Sacrifice

The final body weight of the mice was obtained at the end of the treatment using a digital weighing balance. They were then sacrificed by decapitation twenty four hours after the last treatment. Blood samples were collected and taken in EDTA containing tubes from animals of different groups for haematological measurements. Moreover, mammary tissues were fixed for antioxidant investigation.

Ethical Approval

The study was conducted in accordance with the declaration of Helsinki and was approved by the local institutional review committee and the Health Research Ethics Committee (HREC) of Lagos University Teaching Hospital (LUTH) with HREC assigned number ADM/DCST/HREC/APP/854

\subsection{Haematological Measurements}

Complete blood count (CBC) includes hemoglobin content, red blood cells (RBC), white blood cells (WBC), was done by using Automated Hematology Analyzer, readymade kits and platelets (PLT) counts.

\subsubsection{Determination of Packed Cell Volume (PCV)}

The blood in the EDTA bottle was used for the PVC. The blood was collected into a capillary tube containing anticoagulant. Plug one end of the tube with soft wax to a depth of about $2 \mathrm{~mm}$ by heating it carefully over a flame. Place the capillary tube in the numbered slots in heaematocrit centrifuge. After centrifuge at high speed $(13000 \mathrm{rpm})$ for 5 minutes. The percentage of PVC is determined using haematocrits was calculated based on the following formula

$$
\mathrm{Ht}=\frac{L 1}{L 2} \times 100
$$

Where,

$\mathrm{Li}=$ is the height of $\mathrm{RBC}$ column

$\mathrm{L} 2=$ is the total length of the column $(\mathrm{RBC}+$ Plasma + buffy coat) in millimeter and expressed in per cent

\subsubsection{Determination of Total White Blood Cell Counts}

The counting of total white blood cells was done by using a diluting fluid (Turk's fluid) in a ratio of 1:20 which haemolyses the RBCs leaving the WBCs to be counted. The leukocytes are the counted in a counting chamber under the microscope, and the number of cells in a litre of blood is calculated.

\subsubsection{Determination of Heamoglobin (Hb)}

Sahli's haemoglobinometer was employed for estimation of haemoglobin $(\mathrm{Hb})$ content of the blood. Shahi's pipette was filled with mice blood exactly up to $20 \mathrm{~mm}^{3}$ mark. The excess of blood was removed by blotting the tip with soft absorbent tissue. The blood was expelled into a calibrated (transmission) test tube containing $1 \mathrm{ml}$ of $0.1 \mathrm{~N} \mathrm{HCl}$ acid solutions and the pipette was rinsed several times in the acid solution. The sample was allowed to stand for 3 minutes. This method involves conversion of hemoglobin to acid haematin. The amount of haemoglobin in the blood sample was directly read in gram percent from the graduated haemoglohinometer tube.

\subsubsection{Other Blood Indices}

Haematological indices such as Mean Corpuscular Volume (MCV), Mean Corpuscular Haemoglobin Concentration (MCHC) and Mean Corpuscular Haemoglobin ( $\mathrm{MCH})$ were calculated from the values of $\mathrm{Hh}$ content $(\%)$ and $\mathrm{Ht}(\%)$ using the following formula
1) $\mathrm{MCV}(\mathrm{fL})=\frac{\operatorname{PCV}(\%) \times 100}{\mathrm{RBC} \text { count }}$
2) $\mathrm{MCH}(\mathrm{pg})=\frac{\mathrm{Hb}(\mathrm{g} / \mathrm{dl}) \times 100}{\mathrm{RBC} \text { count }}$
3) $\operatorname{MCHC}(g / d l)=\frac{H b(g / d l) \times 100}{\text { PCV }(\%)}$

\subsubsection{Differential Blood Counts (DC)}

The differential counting was done as described in clinical haematology. The blood smears were made, air-dried, fixed in $100 \%$ methanol and stained with May and Grunwald stain and counted under oil immersion objective. Smears were examined for macrophages and abnormal RBC morphology (size, shape, colour, maturity, inclusions) and to determine the differential count of white blood cells (WBC). Total of 1000 blood cells of all types was counted from each smear and then percentage of each cell type was calculated.

1) Since the May-Grünwald staining solution is made up in $\mathrm{MeOH}$ prior fixation is not necessary.

2) Place slide on a flat surface and pipet $500 \mu$ MayGrünwald Stain on the slide, leave for $3 \mathrm{~min}$.

3) Dilute Stain by adding $500 \mu 10 \mathrm{mM}$ NaPi 7.0, leave for $7 \mathrm{~min}$.

4) Lift slide to drain the staining solution and place in a 
tray with $\mathrm{H}_{2} \mathrm{O}$ for 1 min.

5) Dry slide vertically for $5 \mathrm{~min}$.

6) Mount coverslips using an aqueous-based mounting medium.

\subsection{Biochemical Analyses}

\subsubsection{Sample Preparation (Tissue Homogenate)}

Breast tissues were collected from above groups and processed. Breast tissue was perfused with saline to remove any red blood cells and clots. Tissue was homogenized with the saline $(0.9 \%)$ ( $1 \mathrm{~g}$ breast in $10 \mathrm{ml}$ saline $)$ with ice-cold PBS pH 8.0 using a homogenizer (Yamato LSC LH-21, Japan) and centrifuged at $12,000 \mathrm{rpm}$ for $30 \mathrm{~min}$ at $4^{\circ} \mathrm{C}$. Supernatant was collected and used for following biochemical estimations.

\subsubsection{Protein Estimation}

Total protein contents were estimated by the modified method of Lowry et al. (1951). $0.5 \mathrm{ml}$ of homogenized tissue is mixed with $1.5 \mathrm{ml}$ of $0.2 \mathrm{M}$ Tris buffer $(\mathrm{pH}-8.2)$ and $0.1 \mathrm{ml}$ of $0.01 \mathrm{M}$ DTNB and this mixture is brought to $10.0 \mathrm{ml}$ with $7.9 \mathrm{ml}$ of absolute methanol. The above reaction mixture is centrifuged at approximately $300 \mathrm{~g}$ at room temperature for 15 minutes. The absorbance of supernatant is read in a spectrophotometer against reagent blank (without sample) at $412 \mathrm{~nm}$. Tissue protein is than calculated with reference to the standard graph and the results were expressed as milligram protein per gram of tissue weight.

$$
\text { Protein content }=\frac{\text { OD sample } \times 58.48}{\text { OD standard }}
$$

Where;

$\mathrm{OD}=$ Optical density at $412 \mathrm{~nm}$

\subsubsection{Estimation of Glutathione}

Glutathione (GSH) contents were measured as total nonprotein sulfhydryl (NPSH) group using the method of Moron et al. (1979) with modifications. For the measurement of GSH content, $1.6 \mathrm{ml}$ sodium phosphate buffer, $0.1 \mathrm{ml}$ of 1 $\mathrm{mM}$ ethylenediamine tetra acetic acid disodium salt (EDTA, Amresco), $0.1 \mathrm{ml}$ nicotinamide adenine dinucleotide phosphate reduced (NADPH) and $0.1 \mathrm{ml}$ oxidized glutathione as well as PMS $(0.1 \mathrm{ml})$ in total volume of $2 \mathrm{ml}$. The enzyme activity is measured at $340 \mathrm{~nm}$ and calculated as nanomole NADPH oxidized $/ \mathrm{min} / \mathrm{mg}$ of protein using extinction coefficient of $1.36 \times 10^{3} \mathrm{M} / \mathrm{cm}$. The change in absorbance/min was determined and this value was converted to micromole GSH in comparison to a known standard.

$$
\mathrm{GSH}=\frac{\text { OD sample } \times 45 \times 10^{3}}{1.36 \times 10^{3}}
$$

Where;

$\mathrm{OD}=$ Optical density at $340 \mathrm{~nm}$

$1.36 \times 10^{3}=$ Extinction coefficient

\subsubsection{Estimation of Superoxide Dismutase Activity (SOD)}

Superoxide dismutase (SOD) activity was assayed by the nitroblue tetrazolium (NBT) method as described by Beauchamp et al. (1971). In this method, the reaction mixture consists of $0.5 \mathrm{ml}$ supernatant, $1 \mathrm{ml}$ of $50 \mathrm{mM}$ Sodium carbonate, $0.4 \mathrm{ml}$ of $25 \mu \mathrm{M}$ NBT, $0.2 \mathrm{ml}$ of $0.1 \mathrm{mM}$ EDTA. The reaction is then initiated by the addition of $0.4 \mathrm{ml}$ of $1 \mathrm{mM}$ hydroxylamine hydrochloride. The change in absorbance is recorded at $560 \mathrm{~nm}$ using a UV spectrophotometer. The control is simultaneously run without homogenate. Units of SOD activity are expressed as the amount of enzyme required to inhibit the reduction of NBT by $50 \%$. Specific activity of total SOD is expressed as units per milligram protein.

$$
\text { SOD }=\frac{\text { OD sample } \times 100 \times 10^{6}}{4020} \div \text { Protein content }
$$

\subsubsection{Estimation of Catalase in Breast}

Catalase (CAT) activity was determined by catalytic reduction of hydrogen peroxide using a standard method described by Aebi (1984). The mixture consists of $1.95 \mathrm{ml}$ of phosphate buffer $(0.05 \mathrm{M}, \mathrm{pH}-7), 1 \mathrm{ml}$ of H2O2 (0.019 M) and $0.05 \mathrm{ml}$ sample $(10 \% \mathrm{w} / \mathrm{v})$ in a final volume of $3 \mathrm{ml}$. control cuvette contains all the components except substrate. Change in absorbance is then recorded at $240 \mathrm{~nm}$ and the results were expressed as micromole of product formed per minute per milligram protein of the tissue.

$$
\text { CAT }=\frac{\text { OD sample } \times 15 \times 10^{3}}{40} \div \text { Protein content }
$$

\subsubsection{Estimation of Malondialdehyde Level in breast}

MDA levels, an index of lipid peroxidation were measured by double heating method of Okhawa et al, (1979). The method is based on spectrophotometric measurement of the purple colour generated by the reaction of TBA with MDA. For this purpose, $2.5 \mathrm{~mL}$ of trichloroacetic acid solution $(10 \% \mathrm{w} / \mathrm{v})$ was added to $0.5 \mathrm{~mL}$ homogenized tissue in each centrifuge tube; the tubes were then placed in a boiling water bath for $15 \mathrm{mins}$. After cooling to room temperature, the tubes were centrifuged at $1000 \mathrm{xg}$ for $10 \mathrm{mins}$ and $2 \mathrm{~mL}$ of each sample supernatant was transferred to attest tube containing 1 $\mathrm{mL}$ of TBA solution $(0.67 \% \mathrm{w} / \mathrm{v})$. Each tube was then placed in a boiling water bath for $15 \mathrm{~min}$. After cooling at room temperature, the absorbance was measured at $532 \mathrm{~nm}$ by using spectrophotometer. The concentration of MDA was calculated based on absorbance coefficient of the MDA complex $\left(\mathrm{e}=1.56 \times 10^{5} \mathrm{cmM}^{-1}\right)$.

$$
\text { MDA }=\frac{\text { OD sample } \times 21 \times 10^{6}}{1.56 \times 10^{5}}
$$

Where;

$\mathrm{OD}=$ Optical density at $532 \mathrm{~nm}$

$1.56 \times 10^{5}=$ Extinction coefficient

\subsection{Statistical Analysis}

Experimental results are expressed as mean \pm standard error of the mean (mean \pm S.E.M). The data were analysed by ANOVA $(p<0.05)$ and means separated by Duncan's multiple 
range tests (by SPSS version 21 software). Tabulation and graphics of data were done using Microsoft Excel XP.

\section{Result}

\subsection{Morphological Results}

Table 2 demonstrates the changes in the body weight of mice after induction of NMU and during the periods of treatment with extracts. There was a significant difference at $(p<0.05)$ between the treatment groups and normal control group, which signifies the extracts increases the weight of the animals. Figure 1 illustrates that the weight between all
Alcoholic extracts-treated groups and controls were significantly different $(\mathrm{P}>0.05)$.

Table 2. Mean initial and final body weight of adult female mice.

\begin{tabular}{lll}
\hline Groups & Initial weight (g) & Final weight (g) \\
\hline A (Normal control) & $14.6 \pm 0.37$ & $19.2 \pm 1.01$ \\
B (Cisplatin) & $16.9 \pm 0.40$ & $19.6 \pm 0.55$ \\
C $(100 \mathrm{mg} / \mathrm{kg})+$ cisplatin & $17.6 \pm 0.16$ & $21.5 \pm 1.04$ \\
D $(200 \mathrm{mg} / \mathrm{kg})+$ cisplatin & $19.6 \pm 0.16$ & $19.8 \pm 0.85$ \\
E $(400 \mathrm{mg} / \mathrm{kg})+$ cisplatin & $20.5 \pm 0.26$ & $23.7 \pm 0.88$ \\
\hline
\end{tabular}

In Table 2. Results expressed as mean \pm S.E.M of the mean body weight of female mice during the experiment in grams

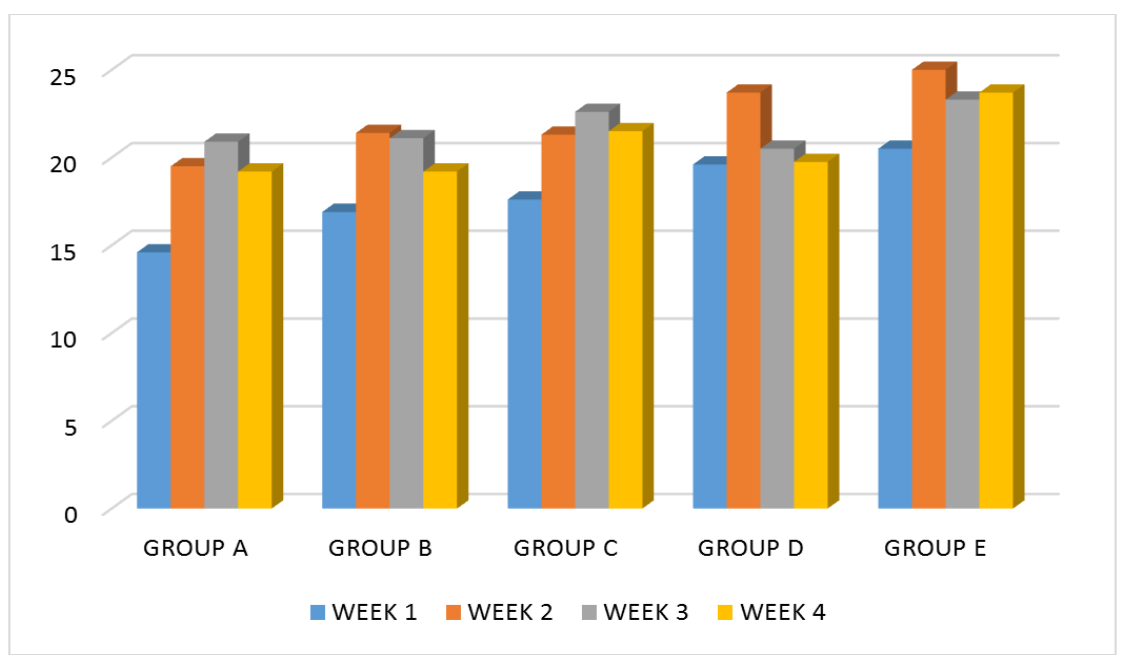

Figure 1. Change in the body weight mice treated with dose of alcoholic extracts.

\subsection{Organ to Body Weight Ratio}

The organ to body weight ratios of Alcoholic extracts treated groups and controls are illustrated in Table 3. The treatment groups $(100,200$ and $400 \mathrm{mg} / \mathrm{kg}$ of extracts) and the positive control showed significant increase of lung, heart and liver to body weight ratio $(\mathrm{P}<0.05)$ compared to the negative control. The liver to body weight ratio of the 400 $\mathrm{mg} / \mathrm{kg}$ Alcoholic extracts-treated group decreased significantly $(\mathrm{P}<0.05)$ compared to the positive control.

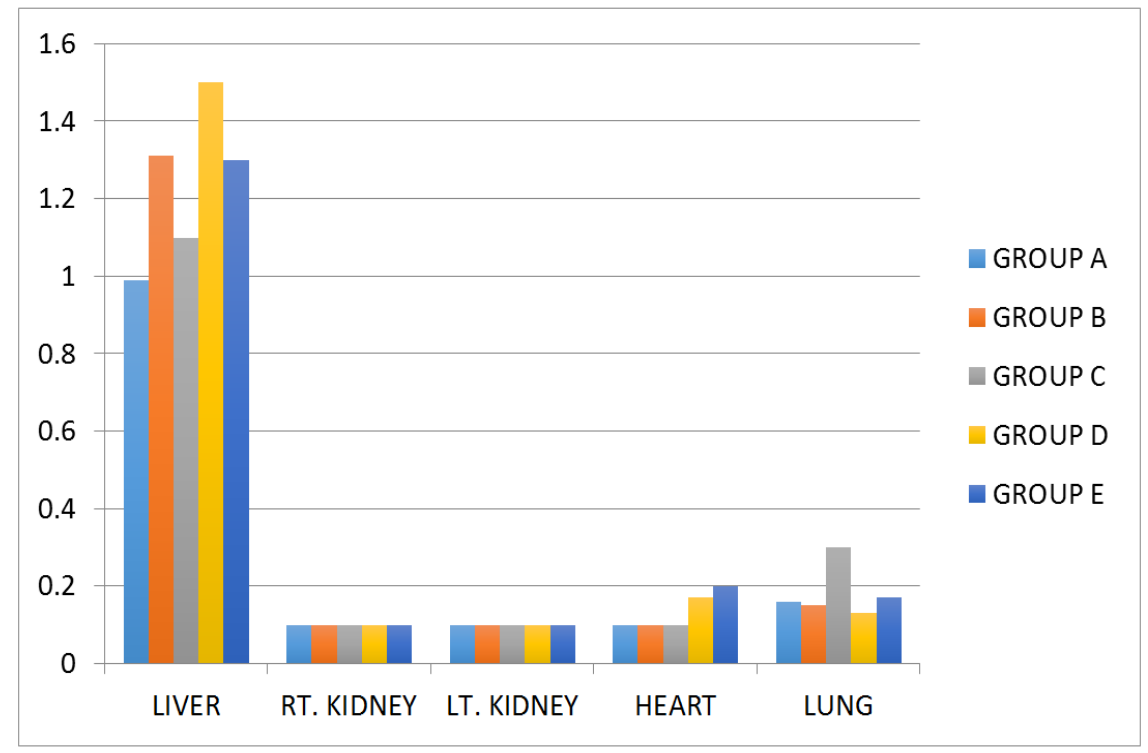

Figure 2. Organ to body weight ratio mice treated with extract. Mean were significantly different $(P<0.05)$. 
Table 3. Mean organs to body weight ratio of adult mice weight.

\begin{tabular}{|c|c|c|c|c|c|}
\hline & LIVER & RT.KIDNEY & LT. KIDNEY & HEART & LUNG \\
\hline A(control) & $0.99 \pm 0.03$ & $0.1 \pm 0$ & $0.1 \pm 0$ & $0.1 \pm 0$ & $0.16 \pm 0.02$ \\
\hline B (Cisplatin) & $1.31 \pm 0.02$ & $0.1 \pm 0.0$ & $0.1 \pm 0.0$ & $0.1 \pm 0.0$ & $0.15 \pm 0.02$ \\
\hline $\mathrm{C}(100 \mathrm{mg} / \mathrm{kg})$ & $1.1 \pm 0.0$ & $0.1 \pm 0.0$ & $0.1 \pm 0.0$ & $0.1 \pm 0.0$ & $0.3 \pm 0.0$ \\
\hline $\mathrm{D}(200 \mathrm{mg} / \mathrm{kg})$ & $1.5 \pm 0.05$ & $0.1 \pm 0.0$ & $0.1 \pm 0.0$ & $0.1 \pm 0.0$ & $0.13 \pm 0.33$ \\
\hline $\mathrm{E}(400 \mathrm{mg} / \mathrm{kg})$ & $0.27 \pm 0.21$ & $0.1 \pm 0.0$ & $0.1 \pm 0.0$ & $0.2 \pm 0.0$ & $0.17 \pm 0.06$ \\
\hline
\end{tabular}

In Table 3, results expressed as Mean \pm Standard Error Mean (S.E.M) of the mean organs to body weight of the mice during the experiment in grams. Values were significantly different $(\mathrm{p}<0.05)$.

\subsection{Antioxidant Biomarkers Result}

Table 4 shows results obtained from the evaluation of selected antioxidants biomarkers of breast tissues of experimental mice. There is no significant difference
$(\mathrm{P}>0.05)$ in the value obtained from catalase activity, superoxide dismutase and total protein when compare to the control groups, however, glutathione and malondialdehyde showed significant difference $\mathrm{p}<0.05$ at plant concentration of $100 \mathrm{mg} / \mathrm{kg}, 200 \mathrm{mg} / \mathrm{kg}$ and $400 \mathrm{mg} / \mathrm{kg}$ respectively. There is also a significant difference in the superoxide dismutase values of the cisplatin group and control group. The levels in the antioxidant parameters indicating biomarkers of mammary gland are illustrated in Figure 3.

Table 4. Comparison of selected antioxidants biomarker of mammary gland of experimental mice.

\begin{tabular}{|c|c|c|c|c|c|c|}
\hline $\mathbf{S} / \mathbf{N}$ & Antioxidant Biomarkers & Control & Cisplatin & $100 \mathrm{mg} / \mathrm{kg}$ & $200 \mathrm{mg} / \mathrm{kg}$ & $400 \mathrm{mg} / \mathrm{kg}$ \\
\hline 1 & Catalase & $1.01 \pm 0.00$ & $1.44 \pm 0.01$ & $* 1.02 \pm 0.00$ & $* 0.98 \pm 0.01$ & $* 0.96 \pm 0.01$ \\
\hline 2 & Superoxide Dismutase & $12.5 \pm 0.36$ & $9.10 \pm 0.51$ & $14.0 \pm 0.38 *$ & $9.56 \pm 0.38$ & $* 14.0 \pm 0.26$ \\
\hline 3 & Glutathione & $4.00 \pm 0.19$ & $4.57 \pm 0.02$ & $* 3.8 \pm 0.02$ & $* 3.67 \pm 0.02$ & $* 3.56 \pm 0.03$ \\
\hline 5 & Total protein & $43.55 \pm 0.15$ & $45.56 \pm 0.20$ & $* 44.4 \pm 0.20$ & $* 45.95 \pm 0.13$ & $* 44.4 \pm 0.20$ \\
\hline
\end{tabular}

Values are means of 3 replicates \pm Standard Error of the Mean (S.E.M) and Values carrying superscript (*) Non-significant between control groups and animal treated with dose of $(100 \mathrm{mg} / \mathrm{Kg}, 200 \mathrm{mg} / \mathrm{Kg}$ and $400 \mathrm{mg} / \mathrm{Kg})$ of alcoholic extract

Antioxidant Biomarkers

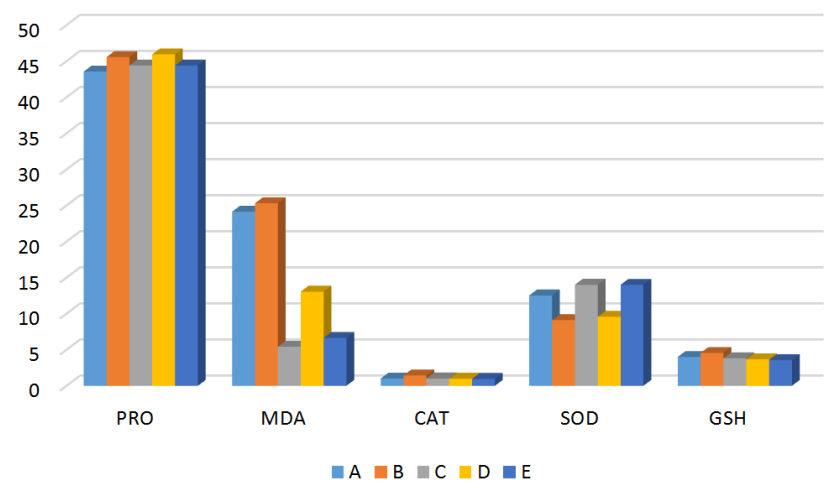

Figure 3. Antioxidant profile in control and experimental female mice.

\subsection{Effect of Plants Extract on the Haematological Parameters}

Studying the haematological parameters revealed that there is a significant $(p \leq 0.05)$ decrease in white blood counts (WBCs), red blood counts (RBCs), Platelets count (PLC) and counts in addition to haemoglobin count after administration of $100 \mathrm{mg} / \mathrm{Kg}, 200 \mathrm{mg} / \mathrm{Kg}$ and $400 \mathrm{mg} / \mathrm{Kg}$ body weight, respectively, while the dose of $100 \mathrm{mg} / \mathrm{Kg}$ body weight induced changes when compare with normal control group. Moreover, none of these doses cause any change in the platelet count as shown in Table 5. Comparing the values of the treated groups were significantly effective when compared with $100 \mathrm{mg} / \mathrm{Kg}$ treated one $(\mathrm{p}<0.05)$ for $\mathrm{RBCs}$.
$200 \mathrm{mg} / \mathrm{Kg}$ treated group showed appreciated $\mathrm{Hb}$ content when compare with $100 \mathrm{mg} / \mathrm{Kg}$ and $400 \mathrm{mg} / \mathrm{Kg}$ treated ones (Figure 4).

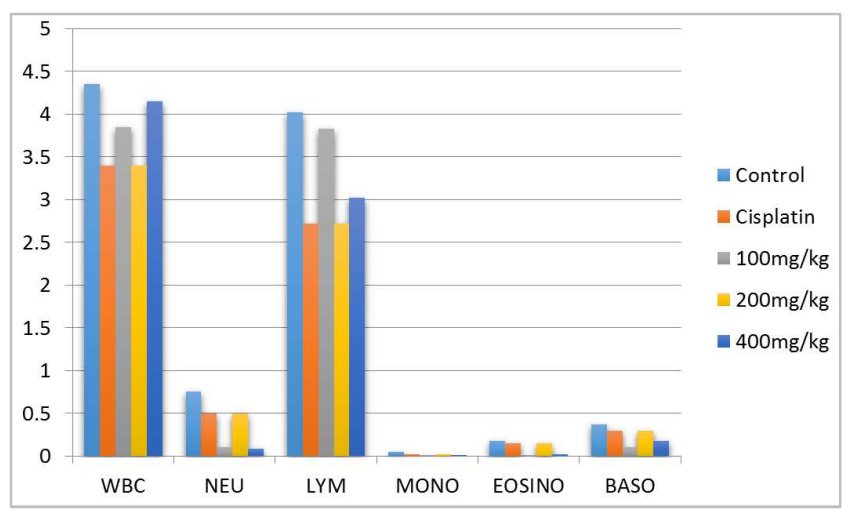

Figure 4. Effect of plants extract on the Haematological parameters.

The mean PCV in control group was $35.00 \pm 0.00 \%$ while those of $100 \mathrm{mg} / \mathrm{kg}, 200 \mathrm{mg} / \mathrm{kg}$ and $400 \mathrm{mg} / \mathrm{kg}$ dose groups were $34.5 \pm 0.50 \%, 33.5 \pm 2.0 \%$ and $32.00 \pm 1.00 \%$ respectively. The mean PCV of the $100 \mathrm{mg} / \mathrm{kg}$ and $400 \mathrm{mg} / \mathrm{kg}$ dose group were significantly different from that of control group $(\mathrm{P}<0.05)$ while the medium dose group was not significantly different. Also, the mean $\mathrm{Hb}$ (Haemoglobin) concentration in $100 \mathrm{mg} / \mathrm{kg} \quad(2.0 \pm 0.30 \mathrm{~g} / \mathrm{dl})$ and $400 \mathrm{mg} / \mathrm{kg}$ dose $(5.65 \pm 0.15 \mathrm{~g} / \mathrm{dl})$ groups were statistically significant compared with control group $(12.25 \pm 0.15 \mathrm{~g} / \mathrm{dl})$ while that of $200 \mathrm{mg} / \mathrm{kg}$ dose group $(12.05 \pm 0.10 \mathrm{~g} / \mathrm{dl})$ did not differ from control values. The mean platelet count of $100 \mathrm{mg} / \mathrm{kg}$ 
$\left(223.00 \pm 7.00 \times 10^{3}\right.$ cells $\left./ \mathrm{mm}^{3}\right), 200 \mathrm{mg} / \mathrm{kg}\left(605 \pm 11.00 \times 10^{3}\right.$ cells $\left./ \mathrm{mm}^{3}\right)$ and $400 \mathrm{mg} / \mathrm{kg}$ dose $\left(399 \pm 2.50 \times 10^{3}\right.$ cells $\left./ \mathrm{mm}^{3}\right)$ groups were significantly different compared with that of control group $\left(920.00 \pm 247 \times 10^{3}\right.$ cells $\left./ \mathrm{mm}^{3}\right)$. The mean values of MCV for the control, $100 \mathrm{mg} / \mathrm{kg}, 200 \mathrm{mg} / \mathrm{kg}$ and $400 \mathrm{mg} / \mathrm{kg}$ dose groups were $48.00 \pm 3.00,49.50 \pm 1.50$, $50.50 \pm 1.50$ and $47.00 \pm 2.001 \mathrm{fL}$ respectively. These values were not significantly different from each other. The mean values of $\mathrm{MCH}$ were also not significantly different among the groups when compared with the control group $(18.50 \pm 0.50 \mathrm{pg})$. Also, the $100 \mathrm{mg} / \mathrm{kg}(38.90 \pm 1.00 \mathrm{~g} / \mathrm{dl}), 200$ $\mathrm{mg} / \mathrm{kg}(33.00 \pm 1.00 \mathrm{~g} / \mathrm{dl})$ and $400 \mathrm{mg} / \mathrm{kg}(39.00 \pm 1.50 \mathrm{~g} / \mathrm{dl})$ dose groups of $\mathrm{MCHC}$ were significant different compared with the control group $(39.50 \pm 1.00 \mathrm{~g} / \mathrm{dl}, \mathrm{P}>0.05)$.

Table 5. Effect of oral administration of daily doses of Alcoholic extract on haematological parameters of normal female mice.

\begin{tabular}{|c|c|c|c|c|c|}
\hline PARAMETERS & Control & Cisplatin & $100 \mathrm{mg} / \mathrm{kg}$ & $200 \mathrm{mg} / \mathrm{kg}$ & $400 \mathrm{mg} / \mathrm{kg}$ \\
\hline Red Blood cell & $7.34 \pm 0.40$ & $6.57 \pm 0.37$ & $0.95 \pm 0.08$ & $* 6.57 \pm 0.08$ & $3.55 \pm 0.55$ \\
\hline Haemoglobin & $12.25 \pm 0.15$ & $12.05 \pm 0.05$ & $2.0 \pm 0.30$ & $* 12.05 \pm 0.10$ & $5.65 \pm 0.15$ \\
\hline PVC & $35.50 \pm 0.0$ & $34.5 \pm 0.50$ & $* 33.5 \pm 0.50$ & $* 34.5 \pm 2.0$ & $* 32.00 \pm 0.50$ \\
\hline $\mathrm{MCV}$ & $48.00 \pm 3.0$ & $49.5 \pm 1.50$ & $* 50.5 \pm 1.50$ & $* 49.5 \pm 2.0$ & $* 47 \pm 2.00$ \\
\hline $\mathrm{MCH}$ & $18.50 \pm 0.50$ & $17.00 \pm 0.0$ & $* 17.5 \pm 0.50$ & $* 17.00 \pm 1.0$ & $* 17.5 \pm 0.50$ \\
\hline $\mathrm{MCHC}$ & $38.00 \pm 1.00$ & $33.00 \pm 1.0$ & $* 38.00 \pm 1.0$ & $33.00 \pm 1.0$ & $* 39.5 \pm 1.50$ \\
\hline RDW & $12.9 \pm 0.70$ & $11.85 \pm 0.75$ & $* 11.75 \pm 0.25$ & $* 11.85 \pm 0.10$ & $* 11.3 \pm 0.20$ \\
\hline Neutrophils & $0.76 \pm 0.29$ & $0.5 \pm 0.04$ & $* 0.11 \pm 0.01$ & $* 0.5 \pm 0.02$ & $* 0.09 \pm 0.01$ \\
\hline Lymphocytes & $4.02 \pm 0.58$ & $2.72 \pm 0.28$ & $* 3.83 \pm 0.06$ & $* 2.72 \pm 0.11$ & $* 3.02 \pm 0.01$ \\
\hline Monocytes & $0.05 \pm 0.03$ & $0.025 \pm 0.01$ & $* 0.015 \pm 0.05$ & $* 0.025 \pm 0.00$ & $* 0.015 \pm 0.01$ \\
\hline Eosinophile & $0.18 \pm 0.06$ & $0.15 \pm 0.03$ & $* 0.02 \pm 0.05$ & $* 0.15 \pm 0.00$ & $* 0.02 \pm 0.01$ \\
\hline Basophils & $0.37 \pm 0.23$ & $0.29 \pm 0.16$ & $* 0.11 \pm 0.07$ & $* 0.29 \pm 0.01$ & $* 0.18 \pm 0.01$ \\
\hline Platelets count & $920 \pm 247$ & $905 \pm 262$ & $223 \pm 7.0$ & $605 \pm 11$ & $399 \pm 2.50$ \\
\hline
\end{tabular}

Result expressed as Mean \pm SEM. ANOVA (p value) represents the difference between all groups. $(*)$ Non significant between control groups and animal treated with dose of $(100 \mathrm{mg} / \mathrm{Kg}, 200 \mathrm{mg} / \mathrm{Kg}$ and $400 \mathrm{mg} / \mathrm{Kg})$ of alcoholic extract.

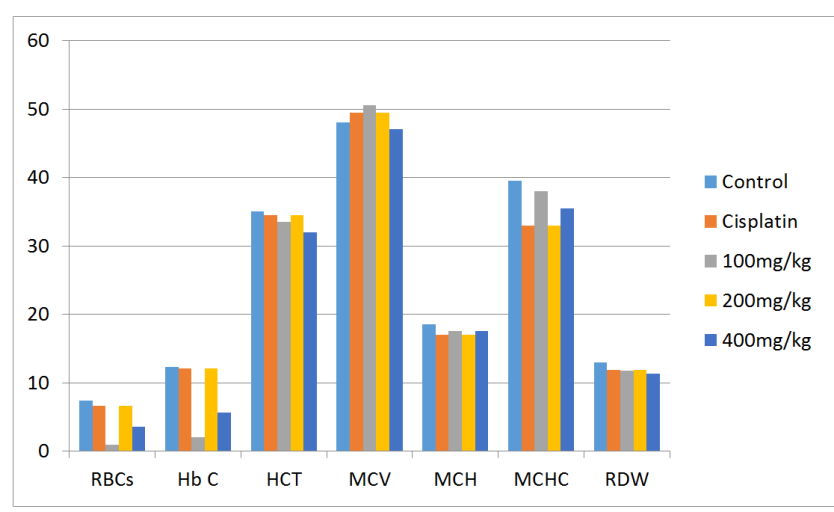

Figure 5. Effect of plants extract on the RBCs, WBCs and Hemoglobin content.

\section{Platelets}

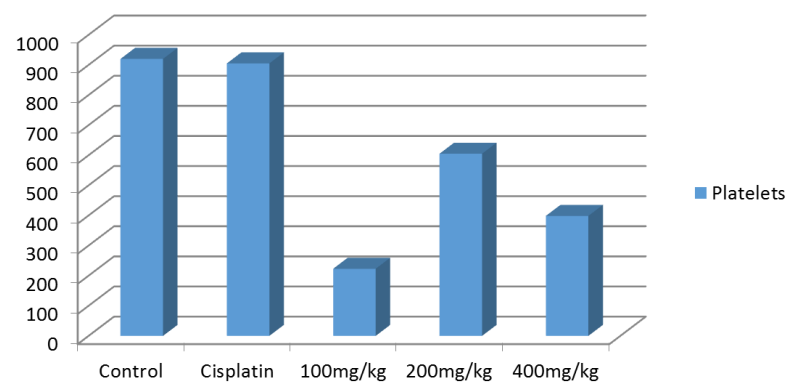

Figure 6. Effect of Alcoholic extracts oral treatment on alteration of Platelets count.

\section{Discussion}

During this study, the routine weight gained over the period of exposure may be due to the presence of some phytochemicals in the extract. Tannins have been previously implicated in increasing body mass [24].. Decreased GSH content observed in this study indicated impairment in cell's defense against ROS and has been known to cause cellular injury [27] and generally reflects the inability of a tissue to scavenge excess superoxide anions leading to oxidative stress $[26,30]$. MDA levels decreased in a dose dependent manner in the breast tissue. A significant MDA decrease was observed due to lipid peroxidation which is a direct indicator that cell membrane damage has occurred in the tissue [7, 22]. Increased CAT observed in this study may indicate enhanced triherbal toleration by that particular tissue [9]. Rise in SOD activities observed may indicate presence of active enzyme involvement in neutralizing the effect of free radicals [12]. Elevated levels of protein content were noticed in all treated mice which may imply that the cell is capable of mitigating effect of free radical and peroxide processes which could ultimately results in modulating the host antioxidant status [32].

The haematological studies of triherbal preparation showed severe anaemia, which may imply inhibition of globin synthesis, depression of erythropoiesis, or a decreased level of folic acid [6, 8, 38]. Extract administration might have caused destruction of erythrocytes directly or the decreased RBC count may be due to the effect of extract on erythropoietic tissue [6]. The manifestation of hypochromic anaemia is due to reduction in the number of red blood cells or haemoglobin or impaired production of erythrocytes [6, 10]. Combine extract might be responsible for the decreased RBCs and haemoglobin levels due to increased level of proinflammatory cytokines that induced iron retention by reticulo-endothelial system, gastrointestinal tract and liver, 
thereby exerting inhibitory effect on erythroid precursors [20] The significant decrease in WBC observed in this study may be alluded to suppression of the haematopoetic system, which consequently reduces the production of WBCs [13], and bio concentration of the toxicant in the kidney and liver [5]. Also, decreased level of white blood cell counts were observed mainly in mice exposed to extract due to the fact that triherbal formula may induce leucopenia and thrombocytopenia in cases of severe liver dysfunction [17] and as a result of decreased defence mechanism against probable attack of toxic molecules during extract toxicosis [23]. Decreased in haematocrit observed in this study can be attributed to the reduction in RBC count caused by either destruction or reduction in size [29].

Variation in $\mathrm{MCV}, \mathrm{MCH}$, and $\mathrm{MCHC}$ values observed in this study may imply that the macrocytic anaemia which can lead to very slow production of erythroblasts in bone marrow [18] which make them grow over in size with shape and have fragile membranes called megaloblast which is characteristic of pernicious anaemia which can lead to megaloblast anaemia [21]. The reduction in $\mathrm{Hb}, \mathrm{RBC}, \mathrm{WBC}, \mathrm{MCV}$, $\mathrm{MCH}$, and $\mathrm{MCHC}$ indicated that there is slow development of blood in the haemopoitic cells [10] due to the presence of saponin in the tri-herbal preparation which has been reported to as reported to suppress haematopoiesis of all blood cells [4].

\section{Conclusion}

In conclusion, the tri-herbal formulations at doses evaluated has potential to induce haematotoxicity, hepatic damage, increase oxidative stress and indiscriminate consumption of high concentrations should be discouraged. Although these medicinal plants may possess profound therapeutic advantages at very low doses. Further research should be carried out in lower doses to ascertain the safety.

\section{References}

[1] Abdullahi, A. A. (2011). Trends and challenges of traditional medicine in Africa. African Journal of Traditional and Complementary and Alternative Medicine. 8: 115-123.

[2] Agnaniet, H., Makani, T., Akagah, A., Menut C. and J. M. Bessiere (2005). Volatile constituents and antioxidant activity of essential oils from Lippia multiflora Mold growing in Gabon. Flavour Fragrance Journal 20: 34-38.

[3] Ahmad, B., Naeem A. K. and Ghufran, A. (2005). Innamudin Pharmacological Investigation of Cassia sophera, Linn. Var. purpurea, Roxb. Medical Journal of Islamic World Academy of Sciences 15(3): 105-109.

[4] Akinnuga, A. M., Bamidele, O., Ekechi, P. and Adeniyi OS (2011). Effects of an Ethanolic Leaf Extract of Gongronema latifolium on Haematological Some Parameters in Rats. Africa Journal of Biomedical Research 14: 153-156.

[5] Amusa, N. A., Ashaye, O. A., and Oladapo, M. O. (2003). Biodeterioration of the African Star apple (Chrysophyllum albidum) in storage and the effect on its food value. Afriica Journal. Of Biotechnology 2: 56 - 57.

[6] Antai A. B., Ofem, O. E., Ikpi, D. E., Ukafia, S. and Agiang, E. A. (2009). Phytochemistry and some haematological changes following oral administration of ethanolic root extract of Physiological Sciences 24 (1), 79-83.

[7] AshokKumar, T. (2004). Antioxidants: New-generation therapeutic base for treatment of polygenic disorders. Current science 86: 496-504

[8] Atasayar, S., Gurer-Orhan, H., Gurel, B. and Ozgunes, H. (2009). Preventive effect of aminiguanidine compared to Vitamin C and vitamin Eon cisplatin -induced nephrotoxicity in rats. Experimental Toxicology and Pathology 61: 23-34

[9] Bandaranayake, W. M. (2006). Qualitycontrol, screening, toxicity, and regulation of herbal Drugs in Modern Phytomedicine. Turning Medicinal Plants into Drugs 6: 2557.

[10] Chia. S., Nagurney, J. T., Brown, D. F., Raffel, O. C., Bamberg, F., Senatore, F., Wackers, F. J. and Jang, I. K. (2009). Association of leucocyte and neutrophil counts with infarct size, left ventricular function and outcome after percutaneous coronary intervention for ST- elevation myocardial infarction. America Journal of Cardiology 103: 333-337.

[11] Choudhury, S., Sharan, L., and Sinha, M. P. (2015). Screening of Some Commonly Used Medicinal Plants against Enteric Human Pathogen Vibrio cholera. European Journal of Medical Physics 9(3): 1-6.

[12] Deger, S., Deger, Y., Ertekin, A., Gul, k. and Ozdal, N. (2008). Determination of the statusof lipid perioxidation and antioxidant in Cattle infected with Dictyocaulus viviparous. Turkish Parasitology 32: 234-237.

[13] Ekiz, C., Agaoglu, L., Karakas, Z., Gurel, N. and Yelcin, I. (2005). The effect of iron deficiency anemia on the function of immune system. Hematological Journal 5: 579-583.

[14] Ekor, M. (2014). The growing use of herbal medicines: issues relating to adverse reactions and challenges in monitoring safety. Frontiers in Pharmacology 2: 1-10.

[15] Fabricant, D. S. and Farnsworth, N. R. (2001). The Value of Plants Used in Traditional Medicine for Drug Discovery. Environmental Health Perspectives. 109: 69-75.

[16] Fatima, A., Singh, P. P., Agarwal, P. I. and Raghuveer, A. S. (2013). Treatment of various diseases by Carissa spinarum 1. A promising shrub. International Journal of Pharmaceutical Sciences and Research 4 (7): 2489-2495.

[17] George, J. N. (2000). Platelets. Lancet 355: 1531 - 1539.

[18] Ghaffar, A. S., Ashraf, R., Hussain, T., Hussain, M., Shafique, S. and Aslam, S. (2014). Clinicohematological disparities induced by triazophos (organophosphate) in Japanese quail. Pakistan Veterinary Journal 34: 257-259.

[19] Hassan, R., Acta, A. and Abdul, B. (2012). A Medicinal Plants (Importance and Uses), Pharmaceutica Analytica 3 (10): 41-52.

[20] Hassan, S. A. Ahmed, W. A. Galeb, F. M. El-Taweel, M. A. and Abu-Bedair, F. A. (2008). In vitro challenge using thymoquinone on hepatocellular carcinoma (HepG2) cell line. Iran Journal of Pharmaceutical Research 7(4): 283-290. 
[21] Hussain, R., Khan, F., Mahmood, S., Rehan, S. and Ali, F. (2014). Clinicohematological and tissue changes induced by butachlor in male Japanese quail (Coturnix japonica). Pest Biochemistry and Physiology 109: 58- 63.

[22] Jonas, C. R., Puckett, A. B., Jones, D. P., Griffith, D. P., Szeszycki, E. E., Bergman, G. F., Furr, C. E., Tyre, C., Carlson, J. L., Galloway, J. R., Blumberg, J. B. and Ziegler, T. R. (2000) Plasma antioxidant status after high-dose chemotherapy a randomized trial of parenteral nutrition in bone marrow transplantation patients. The American Journal of Clinical Nutrition 72: 181-189.

[23] Kori-Siakpere O. (2011). Alterations in some haematological parameters of the African Snakehead: Parachanna africans exposed to cadmium. Notulae Science and Biology 3: 29-34

[24] Marcus, C., Karin, L., Jain, G., Matthias, L. D., Jorns, F., Tilman, G. and Wurgen, S. (2003). Captive roe deer (Capreolus capreolus) select for low amount of tannic acid but not quebracho: flunctuation of preference and potential benefit. Biochemistry and Physiology Part B: Biochemistry and Molecular Biology 136 (2): 369 -382.

[25] Maridass, M. and Britto, A. J. (2008). Origins of Plant Derived Medicines. Ethnobotanical Leaflets 12: 373-387.

[26] Omoregie, E. S. and Osagie, A. U. (2007). Phytochemical Screening and anti-anaemia effect of Jatropha tanjoresis leaf in protein malnourished rats. Plant Achieve 7: 509-516

[27] Omoregie, E. S. and Osagie, A. U. (2011). Effect of Jatropha tanjoresis leaves supplement on activities of some antioxidant enzymes, vitamins and lipid peroxidation in rat. Journal of Food Biochemistry 35(2): 409-424.

[28] Pan, S. Y., Gerhard, L., Si-Hua, G. and Shu, F. Z. (2014). Historical Perspective of Traditional Indigenous Medical Practices: The Current Renaissance and Conservation of Herbal Resources. Evidence-Based Complementary and Alternative Medicine. 2014/525340.

[29] Schneider, C. R., Sheidt, K. and Brietmaier, E. (2003). Four new pregnant glycosides from Gongronema latifolium (Asclepidaceous). Journal Parkische Chem Chenisker-Zutung 353: 532-536.
[30] Shafaquat, N., Syed, T. and Showkat, A. G. (2017). Glutathione-S-transferase, Superoxide Dismutase (GST, SOD) levels, Protein content and lipid Perioxidation in Schizothorax plagiostomus under the infection of pomphorhynchus in Nallah Sukhnag of Kashmir Valley. Pakistan Journal of Biological Sciences 20: 442-446.

[31] Sharaf, S., AKhan, M. Z., Khan, F., Aslam, M. K., Saleemi and Mahmood, F. (2010). Clinico-hematological and micronuclear changes induced by cypermethrin in broiler chicks: their attenuation with vitamin $\mathrm{E}$ and selenium. Experimental Toxicology and Pathology 62: 333-341.

[32] Siwela, A. H., Motsi, L. R. and Dube, S. (2013). Alternation of some hepatic enzyme activities by gastrointestinal helminth parasite in domesticated ostrishes. Advance in Bioresearch 4: $145-150$.

[33] Sofowora, A., Ogunbodede, E., Onayade, A. (2013). The role and place of medicinal plants in the strategies for disease. African Journals Online 10: 210-229.

[34] Telefo, P. B., Lienou, L. L., Yemele, M. D., Lemfack, M. C., Mouokeu, C., Goka, C. S. and Moundipa, F. P. (2011). Ethnopharmacological survey of plants used for the treatment of female infertility in Baham, Cameroon. Journal of Ethnopharmacology, 136(1): 178-187.

[35] Vinha, A. F., Soares, M. O., Castro, A., Santos, A. and Machado, M. (2011). Phytochemical Characterization and Radical Scavenging Activity of Aqueous Extracts of Medicinal Plants from Portugal 2: 335-347.

[36] World Health Organisation (2013). The WHO Traditional Medicine Strategy 2014-2023.

[37] World Health Organization (2005). National policy on traditional medicine and regulation of herbal medicines. Report of a WHO global survey.

[38] Yadav, Y. C., Srivastav, D. N. and Saini T. (2010). Nephroprotective and curative activity of lepidium stivum L. seeds in albino rat using cisplatin-induced acute renal failure. Journal of Pharmaceutical chemistry 2: 57-64. 